\title{
Leaf rust resistance genes identification in the spring bread wheat breeding material of the Agricultural Research Institute for South-East Regions of Russia
}

\author{
${ }^{*}$ Elena Gultyaeva' - Sergei Sibikeev² - Alexander Druzhin² - Ekaterina Shaydayuk ${ }^{2}$
}

1All-Russian Institute of Plant Protection, St. Petershurg, Russia

${ }^{2}$ Agricultural Research Institute for South-East Regions, Saratov, Russia

\begin{abstract}
Summary: Leaf rust caused by Pucinia triticina is a common bread wheat disease in the Volga Region of Russia and breeding for this disease resistance is a priority for the Agricultural Research Institute for South-East Regions wheat program. Knowledge of the effective resistance genes present in the germplasm is relevant when selecting for effective and more durable resistance. P. triticina races with virulence to $L r 9, L r 19, L r 26$ and with other different virulence combinations and molecular markers of $L r$ genes were used to determine which seedling resistance genes might be present in the 68 bread wheat lines and cultivars. Studies have shown that the effective protection against leaf rust widespread in the Volga Region spring bread wheat cultivars is controlled by $L x 6 A g$ and $L 6 A g+\operatorname{Lr} 19$ genes. In addition, cultivars carry Lr10, Lr19, Lr10+Lr26 genes. It was found that in the studied set of lines the leaf rust resistance is determined by the following $L$ rgenes and its combinations: $9,10,19,26,34,37,41$, Satu, $6 . A g$. Moreover, usage frequency of $L x 19$ is $89.5 \%, L r 10-40.4 \%, \operatorname{Lr} 26-31.6 \%, L r 6 g^{8}-21 \%, L r 28-3.5 \%, L r 41-3.5 \%, L r 9$ $1.8 \%, \operatorname{Lr} 34-1.8 \%, \operatorname{Lr} 37-1.8 \%, \operatorname{Lr} S a t u-1.8 \%$. The frequency of two Lrgenes combinations is $45.7 \%$, three $-21 \%$ and four $L r$-genes - 5.3\%. Mainly are used such $L$ rgenes combinations as: $L r 19+L r 26$ and $L r 10+L r 19+L r 26-$ $22.8 \% ; \operatorname{Lr} 19+\operatorname{Lr} 6 A g-7 \%$. The four $L r$ genes combinations has been included $L r 10+L r 26+L r 28 ?+L r 6 A^{*}-1.8 \%$, $L r 1+L 10+L x 26+L x 6 A g-1.8 \%$ and $L r 10+L 19+L x 28 ?+L x 6 A g-1.8 \%$. In addition, the effective $L r 19$ with non identified $L x$-genes from cultivar Saratovskaya 57 (L164) and A. elongatum (CI-7-57) combinations has been identified. Key words: bread wheat, leaf rust, $L r$-genes, molecular markers, resistance
\end{abstract}

\section{Introduction}

The best approach to control diseases such as leaf rust is genetic resistance based on effective resistance genes (Spanic et al., 2015). Unfortunately, many cultivars of winter and spring wheat do not contain effective race-specific resistance, and the breeding for non-racial specific resistance has not received sufficient development. Thus, due to its economic importance, resistance to leaf rust is a priority in the Agricultural

Corresponding author

eigultyaeva@rambler.ru

Acknowledgement:

Supported by Russian Foundation for Basic Researches, grant №18-016-00170a

Cite this article

Gultyaeva E., Sibikeev S., Dtuzhin A., Shaydayuk E. (2019). Leaf tust resistance genes identification in the spring bread wheat breeding material of the Agriculutual Research Institute for South-East Regions of Russia. Ratar. Pont, $56(2), 34-40$.
Research Institute for South-East Regions (ARISER) breeding program. Because, currently, the bread wheat intraspecific genetic variability is unable to provide a sufficient protection degree against pathogens, the most promising in this regard are related wheat species, representatives of the genera Aegilops, Secale, Agropyron. In ARISER Laboratory of Genetic and Cytology during the period 1990-2017, the leaf rust resistant germplasm from such species as T. durum Desf., $A$. elongatum, $A$. intermedium Host, $A$. speltoides Tausch, $A$. ventricosa Tausch, Secale cereale L., triticale cv. Satu and also synthetics of CIMMY'T breeding were used. As a result, set of introgressive linesresistant to leaf and stem rust were obtained. It should be noted that the main direction was the several Lrgenes in one genotype integrating to prolong the resistance effectiveness against the pathogen. Breeding and selection for leaf rust resistance in wheat cultivars can be facilitated by extensive genetic analyses using molecular markers that are linked or resistance specific (Kolmer et al., 2013). 
Also gene postulations are possible because of gene-forgene specificity, where the infection types produced by pathogen isolates on wheat cultivars under study are compared to infection types produced by the same isolates on the so-called differentials, often near isogenic lines, each carrying known single resistance gene (Pathan, Park 2007). But this method has a limitation because if the sample carries two Lr genes it is not always possible to find the corresponding clone test. For example, in the Volga region $L r 19$ and Lr26 genes are inefficient in protecting wheat from leaf rust, despite their combination efficacy ( $\operatorname{rr} 19+\operatorname{Lr} 26)$. Accordingly, the clones virulent to $L r 19$ and $L r 26$ are widely found in the pathogen population, but there are none virulent to both. In this case marker-assisted selection (MAS) combined with traditional breeding techniques has become a valuable tool in selection of individuals carrying genes, controlling the traits of interest, such as disease resistance.

The aim of this study was to determine the leaf rust resistance genes presence in 57 wheat introgression lines and 11 cultivars developed at the ARISER and to postulate the known genes presence based on infection type caused by well-characterized races of these pathogens and using molecular markers.

\section{Materials and Methods}

Sixty-eight spring bread wheat lines and cultivars (Table 1) developed at ARISER Russia and highly resistant to $P$. triticina in the field were tested at the seedling stage for infection types to postulate seedling leaf rust resistance genes. Ten seedlings of each line were grown in the pots with soil and were inoculated with urediniospores suspension of single $P$. triticina race when the first leaf had been fully expanded. Characteristics of using races to 27 isogenic lines are presented in Table 2 . All these 5 isolates had susceptible infection type (3-4) to the Thatcher line with $L r 1, L r 2 b$, Lr2c, Lr3a, Lr3bg, Lr3ka, Lr10, Lr11, Lr14a, Lr14b, Lr16, $L r 17, L r 18, L r 20, L r 21$ and $L r 30$, and resistant type to the Thatcher line with $L r 24, L r 28, L r 29, L r 41$ and $L r 47$. The main variation among races included virulence to $\mathrm{Tc} L r$, TcLr19 and TcLr26.

Plants were kept in $100 \%$ humidity chamber overnight and then maintained in the Versatille Environmental Test Chamber MLR-352H (SANYO Electric Co., Ltd., Japan) at $22^{\circ} \mathrm{C}$. Infection types (IT) were classified on $0-4$ scale during 10-12 days after inoculation on seedlings as described by E.B. Mains and H.S. Jackson (1926), where 0 - no visible uredia; 0 ; hypersensitive flecks; 1 - small uredia with necrosis; 2 from small to medium sized uredia with green islands surrounded by necrosis or chlorosis; 3 - medium sized uredia with or without chlorosis; 4 - large uredia without chlorosis; X - heterogeneous, similarly distributed over the leaves. The plants with 0 to 2 infection types were classified as resistant, 3 to 4 and $\mathrm{X}$ infection types as susceptible.
Leaf rust resistance genes $(L r)$ in wheat cultivars and lines were also determined by molecular markers WR03 (Lrr), SCS5 (Lr), F1.2245/Lr106/r2 (Lr10),

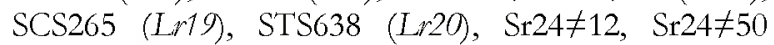
(Lr24), scm9 (Lr26), SCS421 (Lr28), Lr29F24 (Lr29), csLV34 (Lr34), Sr39=22 (Lr35), Verntrip/LN2 (Lr37), GDM35 (Lr41), PS10 (Lr47) and S13-R16 (Lr60) (http://maswheat.ucdavis.edu; Gupta et al., 2005, 2006; Cherukuri et al., 2005; Qiu et al., 2007; Weng et al., 2007; Marais et al., 2010). For Lr10, Lr26, Lr34 and Lr37 genomic DNA was extracted from leaves of three plants belonging to each wheat line using Dorokhov and Kloke (1997). The PCR reactions were carried out as proposed previously (Gultyaeva et al., 2009). The amplified products were visible under UV light after electrophoresis on $1.5 \%$ agarose gels containing ethidium bromide.

\section{Results}

Resistance of 68 introgressive lines and cultivars to leaf rust isolates at seedling plant stages is shown in Table 1. Thirty five wheat samples had resistance (IT $=0$ ) to all races used for multi-pathotype tests. Accordingly, their resistance can be controlled by highly effective Lrgenes, or their effective combinations. Using molecular markers, the combination of $L n 19$ and Lr26 genes was determined for lines №1, №13, №3233, №36 and №38. In lines ㅅo6, №19, №22, №34, №40-41, №45-46, along with these genes, $\operatorname{Lr} 10$ was determined, and in line $N o 20-L 141$-gene. The presence of Lr4lgene in line $\mathfrak{N o 2 0}$ is probably due to the presence of $A$. squarosa ( $=A$. tauschii Coss.) in pedigree. In addition, a combination of $L r 19+L r 41$ genes was determined in line №35. Effective $L r 9$ and $L r 19$ genes combination is revealed in the line №18.

Genes Lr10 and Lr19 were revealed in the highresistant introgressive lines №26, №48, №55-56, and Lr19 gene in the lines №3, №12, №15, №31 and №42. Their resistance to all used races predicts the additional genes presence beyond $\operatorname{Lr} 19$ gene, since other lines carrying Lr10+Lr19, demonstrated a susceptible reaction (Table 1). In line №3, according to its pedigree, the additional gene may be $L r 25$. Genes from durum wheat L164 (Saratovskaya 57) in line №15 may be additional. In lines №42, №48 and №55 gene $L 26 A^{2}$ originates from cultivars Belyanka, Favorit and lines Multi 6R, accordingly. Line №31 has a source of Lr24 gene in its lineage, but this gene has not been identified. Probably, the resistance of this line can be provided by an additional unknown or just a new gene. Furthermore, additional or new resistance genes to leaf rust can be found in lines №26 and №56, in the first one originates from $A$. elongatum (CI-7-57 $2 \mathrm{n}=70$ ), and in the second one originates from the Australian Sr35 gene source.

$L r 1$ and $L r 19$ genes and $L r S p$ gene originates from A. speltoides were revealed in line №10. The $\operatorname{LrS} p$ gene is 
Table 1. Characteristic of bread wheat breeding lines and cultivars for resistance to leaf rust

\begin{tabular}{|c|c|c|c|c|c|c|c|}
\hline \multirow{2}{*}{ № } & \multirow{2}{*}{ Pedigree } & \multirow{2}{*}{ Lrgenes } & \multicolumn{5}{|c|}{ Infection type to races } \\
\hline & & & R1 & $\mathrm{R} 2$ & R3 & $\mathrm{R} 4$ & $\mathrm{R} 5$ \\
\hline 1 & L2032*6/Curinda87 & $\operatorname{Lr} 19 \operatorname{Lr} 26$ & 0 & 0 & 0 & 0 & 0 \\
\hline 2 & Dobrunya*5/Tc Lt9 & Lx10 Lr19 & 0 & 3 & 0 & 0 & 0 \\
\hline 3 & Dobrunya*4/Tc Lr25 & $\operatorname{Lr} 19$ & 0 & 0 & 0 & 0 & 0 \\
\hline 4 & Dobrunya*5//Milan/Prinia L653 & $\operatorname{Lr19}$ & 0 & $3-4$ & 0 & 0 & 0 \\
\hline 5 & Dobrunya*5//Milan/Prinia L654 & $\operatorname{Lr} 19$ & 0 & $3-4$ & 0 & 0 & 0 \\
\hline 6 & L503 Lr19 Lr26 & Lr10 Lr19 Lr26 & 0 & 0 & 0 & 0 & 0 \\
\hline 7 & Saratovskaya55/Ag. el *6// Saratovskaya 29 & $\operatorname{Lr} 19$ & 0 & $3-4$ & 0 & 0 & 0 \\
\hline 8 & S55/Agr.el*4//S29/3/L1015 ?Age(3B)/?Age(3D) & $\operatorname{Lr19}$ & 0 & $3-4$ & 0 & 0 & 0 \\
\hline 9 & L505*2//L503*2/Cuckoo line L195 & $\operatorname{LrSp}$ & 0 & 0 & 0 & 0 & 0 \\
\hline 10 & L505//L503//L583/ Cuckoo line //L505 L200 & $\operatorname{Lr1} \operatorname{Lr} 19 \operatorname{LSP} p$ & 0 & 0 & 0 & 0 & 0 \\
\hline 11 & $\mathrm{~S} 55^{*} 3 / \mathrm{T}$. dic-s//L2032 & $\operatorname{Lr10}$ & 0 & 0 & 0 & 0 & 0 \\
\hline 12 & Dobrunya / Prohorovka//Dobrunya & $\operatorname{Lr19}$ & 0 & 0 & 0 & 0 & 0 \\
\hline 13 & $\mathrm{~L} 2032 * 5 /$ Seri 82 & $\operatorname{Lr} 19 \operatorname{Lr} 26$ & 0 & 0 & 0 & 0 & 0 \\
\hline 14 & L505*2//Croc/Ae.squar(224)//Yaco & $\operatorname{Lr} 19 \operatorname{Lr} 34$ & 0 & $3-4$ & 0 & 0 & 0 \\
\hline 15 & Lud//C55*2/T.dic-s//Saratovskyazolotistaya./L164//S55 & $\operatorname{Lr19}$ & 0 & $0 ; 2$ & 0 & 0 & 0 \\
\hline 16 & S55/Ag. el*6// S29 & $\operatorname{Lr19}$ & 0 & $3-4$ & 0 & 0 & 0 \\
\hline 17 & Dobrunya*4/Nik & $\operatorname{Ln} 19$ & 0 & 3 & 0 & 0 & 0 \\
\hline 18 & Dobrunya*4/3/Croc/Aesquar(205)//Weaver & $\operatorname{Lr} 9 \operatorname{Lr} 19$ & 0 & 0 & 0 & 0 & 0 \\
\hline 19 & L505/3/Croc/Aesquar(205)//Weaver/4/L505/5/C68 & $\operatorname{Lr} 10 \operatorname{Lr} 19 \operatorname{Lr} 26$ & 0 & 0 & 0 & 0 & 0 \\
\hline 20 & L505/3/Croc/Ae.squar(205)//Weaver/4/L505/5/L505 & Lr19 Lr26 Lr41 & 0 & 0 & 0 & 0 & 0 \\
\hline 21 & Belyanka/3/Croc/Ae.squar(205)//Weaver/4/ Belyanka & $\operatorname{Lr} 10 \operatorname{Lr} 26$ & 0 & 0 & 0 & 0 & 0 \\
\hline 22 & Croc/Aesquar(205)//Weaver/3/L505/4/ Belyanka & $\operatorname{Lr} 10 \operatorname{Lr} 19 \operatorname{Lr} 26$ & 0 & 0 & 0 & 0 & 0 \\
\hline 23 & Croc/Aesquar(205)//Weaver/3/L505/4/ DobrunyaLr25 & $\operatorname{Lr} 19$ & 0 & 3 & 0 & $0-1$ & 0 \\
\hline 24 & L12(Dobrunya Lr24)/S68//S68 & $\operatorname{Ln} 10 \operatorname{Ln} 19$ & 0 & $2+$ & 0 & 0 & 0 \\
\hline 25 & S55/Ag. el *5// S29 ( $\left.\mathrm{Ag}^{-}-7 \mathrm{D}\right) / 3 / \mathrm{S} 68$ & $\operatorname{Lr} 10 \operatorname{Lr} 19$ & 0 & $3-4$ & 0 & 0 & 0 \\
\hline 26 & C55/Ag. el*5// C29 (Age-7D)/3/C68 & $\operatorname{Lr10} \operatorname{Lr19}$ & 0 & 0 & 0 & 0 & 0 \\
\hline 27 & Belyanka/3/Altar84/Ae.squar(224)//Pgo/4/C68 (L481/16) & $\operatorname{Lr} 10 \operatorname{Lr} 19$ & 0 & $3-4$ & 0 & 0 & 0 \\
\hline 28 & L505*2/Prohorovka// Belyanka (L496/16) & $\operatorname{Lr} 10 \operatorname{Lr} 26 \operatorname{Lr} 28 ?$ & 0 & 0 & 0 & 0 & 0 \\
\hline 29 & S55*3/T. dic-s//L2032 (L501/16) & Lr1 Lr10Lr26 & 0 & 0 & 0 & 0 & 0 \\
\hline 30 & Dobrunya//6R/Agis181 (L426/16) & $\operatorname{Lr} 10$ & 0 & 0 & 0 & 0 & 0 \\
\hline 31 & Dobrunya/Zolotayavolna// Dobrunya Lr24/3/Dobrunya & $\operatorname{Lr19}$ & 0 & 0 & 0 & 0 & 0 \\
\hline 32 & L505/C42/4/L505*3//Proh//L505/3/S70/4/DobrunyaLr24 & $\operatorname{Lr} 19 \operatorname{Lr} 26$ & 0 & 0 & 0 & 0 & 0 \\
\hline 33 & L505/L164/4/L503//Trap\#1/Bow/3/L503/5/L505/6/C68 & $\operatorname{Lr} 19 \operatorname{Lr} 26$ & 0 & 0 & 0 & 0 & 0 \\
\hline 34 & YV2/L505//L503 Lr26/3/L505/4/S68 & $\operatorname{Lr} 10 \operatorname{Lr} 19 \operatorname{Lr} 26$ & 0 & 0 & 0 & 0 & 0 \\
\hline 35 & Croc/Aesquar(205)//Weaver/3/L505/4/ DobrunyaLr25 & $\operatorname{Lr} 19 \operatorname{Lr} 41$ & 0 & 0 & 0 & 0 & 0 \\
\hline 36 & Dobrunya*5/TcLr9//L505//L503*3/TRAP $\neq$ BOW/Proh/S55 & $\operatorname{Lr} 19 \operatorname{Lr} 26$ & 0 & 0 & 0 & 0 & 0 \\
\hline 37 & $\mathrm{~L} 528 / / \mathrm{C} 55^{*} 4 / \mathrm{T}$.dic-s & $\operatorname{Lr} 19$ & 0 & 3 & 0 & 0 & 0 \\
\hline 38 & Saratovsk zolotistaya/T.dic-s//C58/3/*2 Belyanka/4/Voevoda & $\operatorname{Lr} 19 \operatorname{Lr} 26$ & 0 & 0 & 0 & 0 & 0 \\
\hline 39 & L503Lr26/ Ottan(R11,R12)//Revansh & Lr10Lr19 & 0 & $3-4$ & 0 & 0 & 0 \\
\hline 40 & L18(L503 Lr26)/C68//Revansh & $\operatorname{Lr} 10 \operatorname{Lr} 19 \operatorname{Lr} 26$ & 0 & 0 & 0 & 0 & 0 \\
\hline 41 & Tulaikovskaya 10// Agis181/C29+Agis181/S58 & $\operatorname{Lr} 10 \operatorname{Lr} 19 \operatorname{Lr} 26$ & 0 & 0 & 0 & 0 & 0 \\
\hline 42 & Dobrunya Lr25/Belyanka//L505 & $\operatorname{Lr} 19$ & 0 & 0 & 0 & 0 & 0 \\
\hline 43 & Thatcher $\operatorname{Lr} 37 * 4 / \mathrm{L} 503$ & $\operatorname{Lr} 10 \operatorname{Lr} 19$ & 0 & $3-4$ & 0 & 0 & 0 \\
\hline 44 & Lebedushka & $\operatorname{Lr} 19 \operatorname{LrAgi}$ & 0 & 0 & 0 & 0 & 0 \\
\hline 45 & L.503L t26/Ottan(R11,Rl2)//Revansh & $\operatorname{Lr} 10 \operatorname{Lr} 19 \operatorname{Lr} 26$ & 0 & 0 & 0 & 0 & 0 \\
\hline 46 & YV2/L505//L503 Lr26/3/L505/4/C68 & $\operatorname{Lr} 10 \operatorname{Lr} 19 \operatorname{Lr} 26$ & 0 & 0 & 0 & 0 & 0 \\
\hline 47 & Favorit/ W3534 & $\operatorname{Lr} 19$ & 0 & 3 & 0 & 0 & 0 \\
\hline 48 & Milan/Prinia//*4 Dobrunya/3/Favorit & $\operatorname{Lr10} \operatorname{Lr19}$ & 0 & 0 & 0 & 0 & 0 \\
\hline 49 & S55/Ag. el *6// S29 & $\operatorname{Lr} 10 \operatorname{Lr} 19$ & 0 & $3-4$ & 0 & 0 & 0 \\
\hline 50 & Prohorovka*2/L164*2//L164 & $\operatorname{Lr10} \operatorname{Lr19}$ & 0 & $0-1$ & 0 & 0 & 0 \\
\hline 51 & Celinnaya20/ Dbr// Dbr/3/ DbrLr9/4/Milan/Prinia*4//Dbr & $\operatorname{Lr} 37 \operatorname{Lr} 19$ & 0 & 3,0 & 0 & 0 & 0 \\
\hline 52 & Croc/Ae.squar//Weaver/3/*4 L505/4/S73 & $\operatorname{Lr} 10 \operatorname{Lr} 19$ & 0 & $3-4$ & 0 & 0 & 0 \\
\hline 53 & $\mathrm{~S} 0^{*} 4 / 3 / \mathrm{Croc} /$ Ae squar$(224) / / \mathrm{Yaco}$ & $\operatorname{Ln} 19$ & 0 & 3 & 0 & 0 & 0 \\
\hline
\end{tabular}




\begin{tabular}{ll}
54 & Dobrunya*5//Milan/Prinia/3/Belyanka/4/S68 \\
55 & Prohorovka/MultiLr6R//S68/3/ Dobrunya \\
56 & L503/ Sr 35//L503/3/L503 \\
57 & S74/T.dicoccum k7507*3//S73 \\
58 & Satu/S70//S74/3/S74 \\
59 & Saratovskaya 55 (S55) \\
60 & Saratovskaya 68 (S68) \\
61 & Saratovskaya 70 (S70) \\
62 & Saratovskaya 73(S73) \\
63 & Albidum 32 \\
64 & Prohorovka \\
65 & Yugo-Vostochnaya 2 (YV2) \\
66 & Dobrunya \\
67 & Favorit \\
68 & Voevoda \\
\hline
\end{tabular}

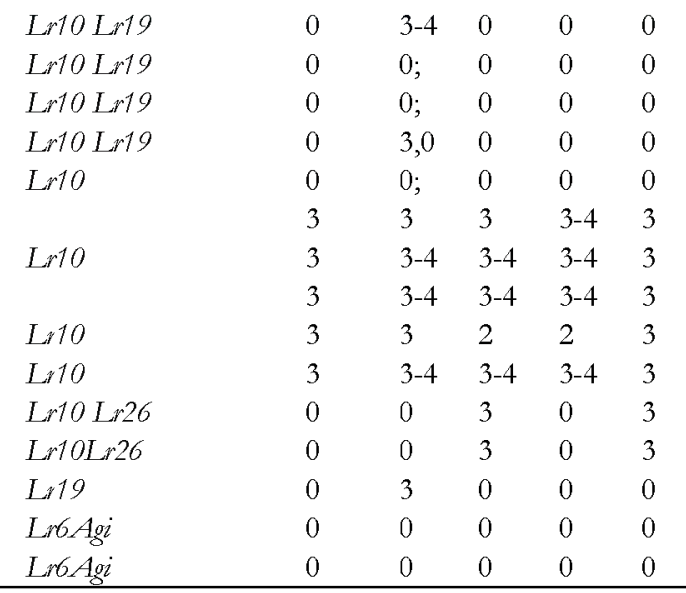

Table 2. Characteristic of Puccinia triticina races used in multi pathotype tests

\begin{tabular}{lll}
\hline Races & Virulence to Lrgenes & Avirulence to Lr genes \\
\hline R1 & 1,2a,2b,2c,3a,3bg,3ka,9,10,11,14a,14b,15,16,17,18,20,21,30 & $19,23,24,26,28,29,41,47$ \\
R2 & 1,2a,2b,2c,3a,3bg,3ka,10,11,14a,14b,15,16,17,18,19,20,21,30 & $9,23,24,26,28,29,41,47$ \\
R3 & 1,2a,2b,2c,3a,3bg,3ka,10,11,14a,14b,15,16,17,18,20,21,26,30 & $9,19,23,24,28,29,41$ \\
R4 & 1,2a,2b,2c,3a,3bg,3ka,10,11,14a,14b,15,16,17,18,20,21,30 & $9,19,23,24,26,28,29,41,47$ \\
R5 & 1,2b,2c,3a,3bg,3ka,10,11,14a,14b, 16,17,18,20,21,26,30 & $2 \mathrm{a}, 9,15,19,23,24,28,29,41$ \\
\hline
\end{tabular}

also identified in line №9. This gene is transferred to these samples from the Cuckoo line, developed with $A$. speltoides participation.

The low-efficiency Lr10 gene was detected in the highly resistant lines №11 and №58. In the line №29 the combination of inefficient genes $L r 1, L r 10$ and $L r 26$ was revealed, in line №21 - Lr10 and Lr26. Undoubtedly, these genes can play a role in these lines resistance strengthening, but lines' №11 and №29 resistance is ensured the most likely by the presence of additional new or unidentified genes from $T$. dicoccoides, in line №58 - from triticale Satu (LrSati), in the line №21 - from cultivar Belyanka $(L / 6 / g)$, since the $L \not 11$ gene from $A$. tauschii hasn't been identified in this line.

The high resistance of cultivars Favorit (№67) and Voevoda (№68) is provided by the gene $\mathrm{Ln}_{\mathrm{Ag}} \mathrm{g}^{2}$ (Sibikeev et al., 2017), an effective marker for which is not provided. Genes $\operatorname{Lr} 10, \operatorname{Lr} 26$ and $\operatorname{Lr} 28$ were specified in line №28 and genes $L r 10$ and $\operatorname{Lr} 28$-in line №30. At the same time, the amplicon size in the TcLr28 line was slightly lower than that of these two lines. It was shown that the SCS421 marker was not strictly specific for this gene (Serfling et al., 2011). Lr28 gene was transferred to bread wheat from $A$ e. speltoides (McIntosh et al., 1995). Donors A. speltoides in pedigree of these lines are absent so this marker presence in lines №28 and №30 may be a false positive result indication. In line №28, according to its pedigree, it can be expected $L 6 A g$ gene presence from cultivar Belyanka, in line №30 from the Agis181 line having the genetic material from A. intermedium (Badayeva E.D., unpublished data).

Along with highly resistant lines and cultivars, 24 lines were identified in the studied collection, which were resistant to all races used, except $\mathrm{R} 2$ race which was virulent to TcLr19 (Table 1). According to the multi-pathogen test, Lrit gene presence can be assumed in these samples. These lines also performed the yellow color of the flour, i.e. a feature linked to Lr19 gene presence. There were cultivars Dobrunya, L503, L505, carrying this gene in the most lines pedigree. Using the marker SCS265, Lr19 gene presence was confirmed in the introgressive lines №2, №4-5, №7-8, №14, №16-17, №23, №24, №25, №27, №37, №39, №43, №47, №49-50, №52-54, №57 and cultivar Dobrynia (№66). In most of the studied lines, Lr19 gene with other ineffective Lrgenes combination was determined, and these actions were not observed in the phytopathological test seedling stage. Their presence in the lines genotypes practically did not affect the reaction type under test clone $\mathrm{R} 2$ inoculation in the seedling phase. Partial resistance Lr34 gene was identified in line №14 which effect appeared in the adult wheat plants phase. The inefficient Lr10 gene, which is widely distributed in ARISER cultivars, has been identified in the lines №2, №24-25, №27, №39, 
№47, №49-50, №52, №54 and №57. All these lines demonstrated $\mathrm{IT}=3$ or $3-4$ while infected with test clone R2 virulent to $L r 19$ except line №24, which IT = $2+$. This may point at the additional Lr-genes presence in this line. Adult plant resistance $\operatorname{Lr} 37$ gene was identified in line №51, probably transferred from cultivars Milan or Prinia. However, resistance cleavage in this line was observed after inoculation by isolates virulent to $\operatorname{Lr} 19$ (R2).

Cultivars Prohorovka and Yugo-Vostochnaya 2 were susceptible to clones virulent to Lr26, indicating that they possessed this gene. This fact was also confirmed using scm9 marker. Along with this one, Lr10 gene was identified in these cultivars. Cultivars Saratovskaya 55, Saratovskaya 68, Saratovskaya 70 and Albidum 32 were susceptible by all used test isolates, and the cultivar Saratovskaya 73 performed a variation in resistance. Ineffective $L r 10$ gene was revealed in Saratovskaya 68 and Saratovskaya 73 cultivars, which had a wide representation in ARISER selection cultivars.

Studies have shown the effective protection against leaf rust having the widespread in Volga Region of Russia spring bread wheat cultivars is controlled only by $L r 6 \mathrm{Ag}^{2}$ and $L \mathrm{~L} / \mathrm{Ag}+\operatorname{Lr} 19$ genes. In addition, cultivars carry Lrgenes - Lr10, Lr19, Lr10+Lr26. It was found that in the studied ARISER breeding set of lines the leaf rust resistance is determined by the combinations following Lrgenes: 9, 10, 19, 26, 34, 37, 41, Satu, $6 \mathrm{Ag}$.

\section{Discussion}

In the Volga region P. triticina is the most severe parasite on both winter and spring bread wheat. The leaf rust epiphytotics are observed on average once every three to four years. In such years, the wheat harvest is reduced up to $20-30 \%$ or more, protein and gluten content in the grain is significantly reduced as well. The analysis of the pathogen epiphytotic chronology shows that in the Volga region the damage from leaf rust has become stronger in recent times than in the first half of the 20th century. The following factors are the main to favor the epiphytotics development. First of all, these are structural changes in wheat acreage. Until 1960s wheat in the Volga region was represented only by spring bread and spring durum wheat, the conditions for maintaining the local $P$. triticina inoculums were unfavorably time-limited (AprilAugust). Currently, the share of spring durum wheat in total wheat crops is less than $10 \%$, spring bread wheat is no more than $25 \%$, but winter bread wheat is more than $65 \%$. Thus, at present moment from spring until late autumn the leaf rust inoculum propagated on live plants both winter and spring wheat. In addition, in the Volga region, there is no wide diversity of cultivars with various resistance genes to leaf rust. For example, in $1960 \mathrm{~s}$ and 1970 winter bread wheat cultivars Mironovskaya 808 and Bezostaya 1 entered the fields, which carried gene $L r 3$, and then there were spring bread wheat cultivars, which also contained a single from Lrgenes - Saratovskaya 46 (Lr14), Ershovskaya 32 (Lr23). In the early 1990s through Volga and the Urals regions there was a rapid widespread of L503, L505 and Samsar cultivars containing the Lr19 gene from A. elongatum. After reaching these cultivars the "critical" plantings area (about 100 thousand hectares), the first pustules of $P$. triticina were found in fields, in Saratov and Orenburg regions simultaneously (Sibikeev et al., 1996). Lr19-gene usage quickly changed P. triticina population structure. To the end of 20 th century in Volga region among the studied 28 Lr-genes already 22 were overcome by pathogen, only Lr9 and Lr24 showed high efficiency (Sibikeev et al., 2007). Wheat rust resistance genetics information in Volga regions is widely available (Gultayeva et al., 2012; Sibikeev et al., 2017). Based on the available information and present research it could be concluded that ARISER wheat leaf rust resistance is based on $\operatorname{Lr1} 9, \operatorname{Lr} 26, \operatorname{Lr} 6 \mathrm{Ag}$ and $L r 10$. Cultivars L503, L505, Dobrynya have the genes Lr10+Lr19, Belyanka, Favorite, Voevoda - LrAg, Lebedushka - L $6 A g+\operatorname{Lr} 19$ (Sibikeev et al., 2017). Leaf rust epiphytotics in 2016-2017 vegetation period in Saratov region showed only Belyanka, Favorite, Voevoda and Lebedushka with genes $\operatorname{LrAg}$, and $L f 6 A^{\prime}+\operatorname{Lr} 19$ having high-efficiency resistance to the pathogen. Breeding and genetic programs for production bread wheat cultivars resistant to leaf rust are impossible without pathogen and its virulent properties study. Studies have shown that many races are generally present in the P. triticina population in Low Volga region and their relative frequencies may change significantly from one year to another (Ivanova et al, 2011). Races with new virulence combinations often overcome cultivars resistance a few years after release. In connection with the above, it is necessary to have and produce a sufficient number of effective genes of resistance to leaf rust and their combinations to provide a diversity of cultivars for them. Our study showed the following diversity and frequency of Lrgenes usage: $\operatorname{Lr} 19$ - 89.5\%, Lr10 - 40.4\%, Lr26 - 31.6\%, Lr $6 \mathrm{Ag}^{\circ}-$ $21 \%, \operatorname{Lr} 28 ?-3.5 \%, \operatorname{Lr} 41-3.5 \%, \operatorname{Lr} 9-1.8 \%, \operatorname{Lr} 34-$ $1.8 \%, \operatorname{Lr} 37-1.8 \%, \operatorname{LrS} a t u-1.8 \%$. The frequency of two $L r$ genes combinations is $45.7 \%$, three $-21 \%$ and four Lrgenes - 5.3\%. Mainly used are such Lrgenes combinations as: $\operatorname{Lr} 19+\operatorname{Lr} 26$ and $L r 10+\operatorname{Lr} 19+\operatorname{Lr} 26-$ $22.8 \% ; \operatorname{Lr} 19+\operatorname{L} 6 A g-7 \%$. Into the four Lrgenes combinations has been included Lr10+Lr26+Lr28? $+L 6 A g-1.8 \%, L r 1+L r 10+L r 26+L 6 A g-1.8 \%$ and $\operatorname{Lr} 10+\operatorname{Lr} 19+\operatorname{Lr} 28 ?+\operatorname{Lr} A \mathrm{~g}^{2}-1.8 \%$. In addition, the effective combination of $L r 19$ with non-identified $L r$ genes from durum wheat cultivar Saratovskaya 57 (L164) and $A$. elongatum ( $2 \mathrm{n}=70 \mathrm{CI}-7-57)$ combinations has been detected. The different countries planting bread wheat have different situation for the diversity of genes for resistance to leaf rust in cultivars and primary breeding material. A study in China in 2015 of 84 bread 
wheat cultivars by test the virulence of 12 races of $P$. triticina and 8 molecular markers of $\operatorname{Lr}$ genes showed that twelve $L r$ genes, including $L r 1, L r 3$, ( $L r 3 b g)$, (Lr3ka), Lr11, Lr13, Lr14a, Lr16, Lr26, Lr27, $L r 30$ and $L r 31$ were postulated to be present either singly or in combinations. Lr3 and Lr26 were detected most often in the tested cultivars, with frequencies of 51.2 and $38.1 \%$, respectively. No wheat $\operatorname{Lr}$ genes were detected in 16 cultivars, and 4 cultivars may carry unknown Lr genes (Xiao-li Ren et al., 2015). In China in 2018, 35 cultivars were tested by 16 Pt-rases and 15 Lr genes molecular markers. Seedlings of 20 tested wheat cultivars showed high resistance phenotype to at least one Pt race. Only three $L r$ genes $(L r 1, L r 10$ and Lr26) were identified in some of the tested cultivars. Five cultivars including Liangxing 66, Hemai 9735, Luyuan 301, Jimai 17, and Taishan 027 showed typical APR reaction in the field. These results indicate that the diversity of known Lr genes in the tested wheat cultivars is relative low (Li J et al., 2018). In the Egypt in 2014 the $\mathrm{similar} s \mathrm{tudy} s \mathrm{how}$ ed te n genes, Lr13, Lr19, Lr24, Lr26, Lr34, Lr35 $L r 36, L r 37, L r 39$, and $L m 46$, were detected in fifteen wheat cultivars. The most frequently occurring genes in fifteen Egyptian wheat cultivars were $\operatorname{Lr} 13, \operatorname{Lr} 24, \operatorname{Lr} 34$, and $\operatorname{Lr} 36$ identified in all the cultivars used, followed by $\operatorname{Lr} 26$ and $\operatorname{Lr} 35(93 \%), \operatorname{Lr} 39$ (66\%), $\operatorname{Lr} 37(53 \%)$, and $L r 46(26.6 \%)$ of the cultivars, and finally $L r 19$ was present in $33.3 \%$ of cultivars. It is concluded that there was a good variation in Lr genes carried by wheat cultivars commercially grown in Egypt (Imbaby et al., 2014).

\section{Conclusion}

The studied breeding lines will be used in breeding programs in Volga region of Russia to expand the genetic diversity of wheat varieties by using alien genes.

\section{References}

Cherukuri, D.P., Gupta, S.K, Charpe, A., Koul S., Prabhu, K.W., Singh, R.B., Haq, Q.M.R (2005). Molecular mapping of Aegilops speltoides derived leaf rust resistance gene Lr 28 in wheat. Eupbytica, 143, 19-26.

Dorokhov, D.B. and Kloke, E. (1997). Rapid and economical technology of RAPD analysis of plant genomes. Mol. Genet., 33(4), 358-365.

Gultyaeva, E. I., Kanyuka, I. A., Alpateva, N. V., Baranova, O. A., Dmitriev, A. P., Pavlyushin, V. A. (2009). Molecular approaches in identifying leaf rust resistance genes in Russian wheat varieties. Russian Agricultural Sriences, 35, 316-319.

Gultyaeva, E.I., Ivanova, O.V., Markelova, T.S., Sibikeev, S.N. (2012). Identification of leaf rusts resistance genes at the introgression bread wheat cultivars and lines produced in the Agricultural Research Institute for South-East Regions of Russia by phytopathologic test and molecular markers. Plant Protection Nens, 1, 38-44. (in Russian)
Gupta, S.K., Charpe, A., Prabhu, K.W., Haque O.M.R. (2006). Identification and validation of molecular markers linked to the leaf rust resistance gene $L x 19$ in wheat. Theor. Appl. Genet., 113, 1027-1036.

Gupta, S.K, Charpe, A, Koul, S Prabhu, KV., Haq, Q.M. (2005). Development and validation of molecular markers linked to an Aegilops umbellulata-derived leaf rust- resistance gene, $\mathrm{Lr}_{\mathrm{r}}$, for marker assisted selection in bread wheat. Genome, 48, 823830.

Imbaby I.A., Mahmoud, M.A., M. Hassan, M. E., Abd-El-Aziz, A. R. M. (2014). Identification of leaf rust resistance genes in selected Egyptian wheat cultivars by molecular markers. The Scientific World Joumal ID 574285, 7 p.

Ivanova, O.V., Markelova, T.S. (2011). The dynamics of structure population of Puccinia recondita f.sp.tritici Rob. et Desm in the Volga region. Protection and Quarantine of Plants, 9, 20-21. (in Russian)

Kolmer, J.A, Mert, Z., Akan, K, Demir, L., Ünsal, R.S., Ermet, C., Keser, M., Akin, B., Morgounov, A (2013). Virulence of l'uccinia triticina in Turkey and leaf rust resistance in Turkish wheat cultivars. Eur. J. Plant Pathol, 135, 703-716.

Li, J., Shi, L., Wang, X., Zhang, N., Wei, X., Zhang, L., Yang, W., Liu, D.2018. Leaf rust resistance of 35 wheat cultivars (lines). J. Plant Pathol. Microbiol., 9, 429.

Mains, E.B., Jackson, H.S.(1926). Physiologic specialization in the leaf rust of wheat; Puccima triticina Erikss. Pbytopathology, 16:89-120.

Marais, G.F., Bekker, T.A., Eksteen A., Fetch, T., Maccallum, B., Marais, A.S. (2010). Attempts to remove gametocidal genes co transferred to common wheat with rust resistance from Aeyilops spettoides. Eupbytica, $171,71-85$

McIntosh, R.A., Wellings, C.R., Park, R.F. (1995). Wheat musts. An atlas of resistance genes. CSIRO Australia, Kluwer Acad. Publ., Dordrecht, the Netherlands.

Pathan, AK., Park R.F. (2007). Evaluation of seedling and adult plant resistance to stem rust in European wheat cultivars. Euphytica, 155, 87-105.

Qiu, J.W., Schürch, A.C., Yahiaoui, N., Dong, L.L., Fan, H.J., Zhang, Z.J., Keller, B., Ling, H.Q. (2007). Physical mapping and identification of a candidate for the leaf rust resistance gene Lr1 of wheat. Theor Appl Genet., 115,159-168.

Ren, X., Liu, T., Liu, B., Gao, L., Chen, W. 2015. Postulation of seedling leaf rust resistance genes in 84 Chinese winter wheat cultivars. Journat of Integrative Agriculture, 14, 1992.2001.

Serfling, A., Krämer, I., Lind, V., Schliephake, E. (2011). Diagnostic value of molecular markers for $\mathrm{Lr}$ genes and characterization of leaf rust resistance of German winter wheat cultivars with regard to the stability of vertical resistance. European Joumal of Plant Pathology, 130, 559-575.

Sibikeev, S.N., Krupnov, V.A, Voronina, S.A., Elesin, V.A. (1996). First report of leaf rust pathotypes virulent to highly effective $L$ r genes transferred from Agropyron species to bread wheat. Plant Breeding, 115, 276-278.

Sibikeev, S.N., Krupnov, V. A.(2007). Evolution of leaf rust and protecting of wheat from it in the Volga region. Bulletin of Saratoy state Agranian University after name N. I. V anilova, pp.92-94.

Sibikeev, S.N., Druzhin, A.E., Badaeva, E.D., Shishkina, A.A. Dragovich, A.Y., Gultyaeva, E.I., Kroupin, P.Y., Karlov, G.I., Khuat, T.M., Divashuk, M.G. (2017). Comparative analysis of Agropyron internedium (Host) Beauv 6Agi and 6Agi2 chromosomes in bread wheat cultivars and lines with wheat-wheatgrass substitutions. Russian Joumal of Genetics, 53, 314 324 .

Spanic, V., Rouse, M.N., Kolmer, J.A., Anderson, J.A. (2015). Leaf and stem seedling rust resistance in wheat cultivars grown in Croatia. Euphytica, 20.3, 4.37-448.

Weng, Y., Azhaguvel, P., Devkota, R.N., Rudd, J.C. (2007). P'CR based markers for detection of different sources of 1AL.1RS and 1BL.1RS wheat-rye translocations in wheat background. Plant Breed., 126, 482486.

Xiao-li, R., Tai-guo, L., Bo, L.,Li, G.,Wan-quan, C. (2015). Postulation of seedling leaf rust resistance genes in 84 Chinese winter wheat cultivars. Joumal of Integrative Agriculture 14(10), 1992-2001. 


\section{Identifikacija gena za otpornost na lisnu rđu u jarom oplemenjivačkom materijalu hlebne pšenice u Poljoprivrednom istraživačkom institutu za jugoistočne oblasti u Rusiji}

\section{Elena Gultyaeva · Sergei Sibikeev · Alexander Druzhin · Ekaterina Shaydayuk}

Sažetak: Lisna rđa hlebne pšenice koju prouzrokuje Pucinia triticina je često oboljenje u oblasti Volge u Rusiji, a oplemenjivanje na otpornost na ovog patogena je prioritetni zadatak programa pšenice u Poljoprivrednom istraživačkom institutu za jugois točne oblasti. Poznavanje efektivnih gena za otpornost koje su prisutne u germplazmi je važno pri oplemenjivanju na efektivnu i dugotrajniju otpornost. Korišćene su rase $P$. triticina sa virulentnošću na Lr9, Lr19, Lr26 i sa drugim kombinacijama različitih virulentnosti i molekularni markeri $L r$ gena u cilju određivanja prisutnosti gena za otpornost u 68 linija i sorti hlebne pšenice. Rezultati pokazuju da se efikasna zaštita od lisne rđe široko rasprostranjena u jarim sortama hlebne pšenice u oblasti Volge kontroliše genima $L{ }^{\prime} A_{g} g^{2}$ i $L r 6 g_{0}+L r 19$. Pored toga, sorte nose i gene $\operatorname{Lr} 10, \operatorname{Lr} 19, \operatorname{Lr} 10+\operatorname{Lr} 26$. U analiziranoj grupi linija, otpornost na lisnu rdu je određena sledećim Lrgenima i njihovim kombinacijama: 9, 10, 19, 26, 34, 37, 41, Satu, 6 Ag. Identifikovan je efikasan $L r 19$ sa neidentifikovanim Lrgenima iz sorte Saratovskaya 57 (L164) i A. elongatum (CI-7-57) kombinacijama.

Ključne reči: hlebna pšenica, lisna rđa, Lrgeni, molekularni markeri, otpornost 